\title{
Variation in milk cortisol during lactation in Murciano-Granadina goats
}

\author{
J. R. Díaz, ${ }^{* 1}$ M. Alejandro, ${ }^{*}$ G. Romero, ${ }^{*}$ F. Moya, ${ }^{*}$ and C. Perist \\ *Departamento de Tecnología Agroalimentaria, Escuela Politécnica Superior de Orihuela, Universidad Miguel Hernández, Ctra. Beniel, \\ 03312 Orihuela, Spain \\ †Instituto de Ciencia Animal, Universidad Politécnica de Valencia, Camino de Vera s/n, 46022 Valencia, Spain
}

\begin{abstract}
Fifty-seven goats were included in an experiment designed to study the effect of lactation stage, parity number, and mammary gland health status on milk cortisol concentration as a method to assess the welfare of Murciano-Granadina goats. The relationships of milk cortisol concentration with different production parameters (milk yield, milk composition, and mechanical milking ability: milk fractioning during milking and milking time) were also studied. The experiment lasted 8 mo and monthly samplings were carried out to determine total milk yield (MY), fractioning during milking (machine milk, MM; machine stripping milk, MSM), and milking time (MT), and a sample was taken from the total milk yield to determine milk cortisol concentration, somatic cell count, and milk composition (fat, protein, and lactose). To determine the infection status of the gland, an aseptic sample was taken for bacteriological analysis before each monthly sampling. Third-parity goats presented higher concentrations of milk cortisol than those of 1,2 , or $\geq 4$ parities. Intramammary infection had no effect on milk cortisol concentration, and somatic cell count did not correlate with cortisol concentration. Cortisol presented a significant correlation with MY and MM, but showed no significant correlation with MSM, MT, or milk composition parameters. Variations in milk cortisol concentration in goats may be associated with different physiological factors in the animal (e.g., milk production level, lactation stage, and parity number) and therefore need not always indicate stress for the animal.
\end{abstract}

Key words: milk cortisol, goat, welfare, mechanical milking

\section{INTRODUCTION}

The last few years have seen growing interest in the level of animal welfare worldwide. The latest legislative actions in the European Union are intended to unify

\footnotetext{
Received April 12, 2012.

Accepted October 7, 2012.

${ }^{1}$ Corresponding author: jr.diaz@umh.es
}

national and international regulations while encouraging member countries to establish better control systems and promote scientific research on animal welfare (Bonafos et al., 2010). One of the indicators most often used for estimating animal welfare in different studies is the determination of cortisol, which is considered a useful tool to monitor the stress response of the hypothalamic-pituitary-adrenal axis (Sevi, 2009).

Most articles on dairy ruminants study the association of plasma cortisol levels with different factors that cause stress in animals, including climatic conditions (Olsson and Dahlborn, 1989; Gudev et al., 2005), management techniques, such as type of food (Marsico et al., 2009), type of housing (Olmos et al., 2009), transport (Canaes et al., 2009), mechanical milking (Negrão et al., 2004), and offspring suckling (Negrão, 2008), and animal-related factors such as mammary gland health status (Fox et al., 1981; Hockett et al., 2000; Decarvalho et al., 2009), lactation stage (Trevisi et al., 2009), breed (Negrão, 2008), parity number (Van Reenen et al., 2002), and milk yield (Sevi et al., 2001).

However, determining plasma cortisol can be stressful due to the method used to extract blood, which has led several researchers to study the association of different factors with cortisol concentration and its metabolites in hair (Comin et al., 2011), urine (Palme et al., 1996), saliva (Negrão et al., 2004), feces (Möstl and Palme, 2002), and milk (Verkerk et al., 1998). Milk cortisol has been determined in studies carried out in cows, which have examined how cortisol concentration varies according to different factors that may or may not cause stress in animals, which in the latter case could be considered a physiological variation of milk cortisol. Cortisol has been used to study the welfare of animals milked using automatic systems (Hagen et al., 2004; Gygax et al., 2006) versus conventional milking parlors and to investigate the association of milk cortisol concentration with animal behavior (Fukasawa and Tsukada, 2010) and with factors related to the animal itself, such as lactation stage, parity number, milk yield, and milk composition (Fukasawa et al., 2008).

Determining cortisol in dairy goat milk can be an easy and noninvasive method to determine which hous- 
ing-, management-, and milking-related factors could be stressful for animals and therefore should not be applied. Therefore, the aim of the present study was to investigate the effect of lactation stage, parity number, and mammary gland health status on milk cortisol concentration in Murciano-Granadina goats, as well as the association of milk cortisol concentration with different parameters (milk yield, milk composition, and mechanical milking ability - milk fractioning during milking and milking time).

\section{MATERIALS AND METHODS}

\section{Animals, Housing, and Management}

The experiment was carried out at the Small Ruminant Educational and Research farm at the Escuela Politécnica Superior de Orihuela de la Universidad Miguel Hernández de Elche (Orihuela, Spain). The goats, all of the Murciano-Granadina breed, were kept together in free stabling conditions with access to an exercise area. The indoor surface area was $1.5 \mathrm{~m}^{2} /$ animal and the total area, including the outdoor pens, was $3.5 \mathrm{~m}^{2}$ /animal. Animals were fed with a commercial mixture (unifeed system) for high-production goats $(2.0 \mathrm{~kg} /$ animal per day) and provided cereal straw and water ad libitum. The reproduction system of the farm was 1 parturition/yr. After parturition, the goats were milked mechanically once a day (0900 h) using a milking machine with electronic production recorders, clusters with an automatic vacuum shut-off valve, and quick exit stalls (Gea-Westfalia-Surge, Bönen, Germany). The routine followed for mechanical milking consisted of placing the teatcups, mechanical milking, and removing the teatcups. Once milking was completed, the teats were immersed in an iodine solution.

\section{Experimental Design and Variables Measured}

One month after parturition, 57 animals were chosen (20 first-parity animals, 16 second-parity animals, 10 third-parity animals, and 11 animals of $\geq 4$ parities) from a group of 64 goats with the same birthing period. Seven goats were excluded because they had the following problems: clinical mastitis (1 goat), production of less than $1 \mathrm{~L}$ of milk (3 goats), only one functioning mammary gland ( 2 goats), or illness ( 1 goat). The experiment lasted 8 mo, starting in February and ending in September, and included 8 sampling days.

On each sampling day, an aseptic sample was taken for bacteriological analysis and 2 milk samples $(50 \mathrm{~mL})$ were taken to determine the SCC. Mechanical milking was then carried out following the stated milking routine. The machine milk yield (without operator intervention, $\mathbf{M M}, \mathrm{mL}$ ) was measured by electronic milk recorders. Afterward, when the milk stream was no longer observed through the short milk tubes of the teatcups, the udder was massaged vigorously without removing the teatcups and the volume of milk given on the electronic measurer was recorded (total milk yield, MY, $\mathrm{mL}$ ) along with the total milking time (MT, s). The difference in volume between MY and MM represented the volume of milk extracted by the machine after the massage given by the operator (machine stripping milk, MSM, mL). Finally, using sampling devices connected to the electronic recorders, a representative sample of the milk $(150 \mathrm{~mL})$ was taken to determine cortisol, SCC, and milk composition.

Milk Cortisol Concentration. Aliquots of refrigerated milk samples $(10 \mathrm{~mL})$ were centrifuged at 2,000 $\times$ $g$ for $20 \mathrm{~min}$ at $4^{\circ} \mathrm{C}$ and the fat layer was removed; then, $10 \mu \mathrm{L}$ of azidiol was added to the skim milk. These refrigerated samples of skim milk were sent to the Endocrinology Laboratory of the Veterinary Faculty (Universidad Complutense de Madrid, Spain). Extraction of cortisol from skim milk samples was performed using a method similar to that described by Hagen et al. (2004) for bovine skim milk. For analysis of cortisol in skim milk samples, an enzyme immunoassay was used that was developed in the laboratory to determine salivary cortisol in cattle (Chacón et al., 2004) and specifically validated for goats following methods described by Munro and Lasley (1988). Skim milk cortisol was expressed in nanograms per milliliter.

$\boldsymbol{S C C}$. Fifty microliters of azidiol was added to a 50$\mathrm{mL}$ aliquot of milk at the farm and then refrigerated at $4^{\circ} \mathrm{C}$ before being sent to the Interprofessional Milk Laboratory in the Valencia Community (Lilcoval, Valencia, Spain), where samples were analyzed according to the ISO/FIL (2006) regulation (fluoro-opto-electronic method; Fossomatic-5000, Foss-Electric S.A, Hillerød, Denmark). Values were expressed in thousands of cells per milliliter.

Milk Composition. Fifty milliliters of milk was used to determine fat content, total protein, and lactose with an automatic infrared spectrophotometry analyzer (MilkoScan FT120, Foss Electric). Results were expressed as grams per kilogram of humid matter.

Bacteriological Analysis. Before milking, bacteriological analysis was carried out on milk samples obtained from teats after carefully cleaning with $70 \%$ ethanol and discarding the first 3 streams of foremilk. Approximately $5 \mathrm{~mL}$ of milk was collected aseptically from each gland. Samples were kept at $4^{\circ} \mathrm{C}$ for up to $12 \mathrm{~h}$ until bacteriological analysis. Twenty microliters of each sample was plated on blood agar plates $(5 \%$ washed sheep erythrocytes; bioMérieux, Lyon, France). The plates were incubated aerobically at $37^{\circ} \mathrm{C}$ and ex- 
amined at 24, 48, and $72 \mathrm{~h}$. Cultures with 5 or more identical colonies were considered positive for IMI.

Mammary gland health status (HS) was defined based on both SCC and results from the bacteriological analysis. Health statuses were as follows: negative bacteriology (no IMI in either gland) and SCC $<1,000$ $\times 10^{3}$ cells $/ \mathrm{mL}$ (FREE1); positive bacteriology (IMI in one or both glands) and SCC $>1,000 \times 10^{3}$ cells/ $\mathrm{mL}$ (IMI1); positive bacteriology and $\mathrm{SCC}<1,000 \times$ $10^{3}$ cells/mL (IMI2); negative bacteriology and SCC $>1,000 \times 10^{3}$ cells $/ \mathrm{mL}($ FREE2; i.e., high SCC due to physiological causes).

Climatic Conditions. Throughout the experiment, the climatic conditions - temperature $\left(\mathbf{T},{ }^{\circ} \mathrm{C}\right)$ and relative humidity (RH, \%) — on the farm were recorded using an automatic meteorological station (Thies CLIMA Sch 5974, Adolf Thies GmbH \& Co. KG, Gottingen, Germany). Every hour, the equipment recorded the average, minimum, and maximum $\mathrm{T}$ and $\mathrm{RH}$ values. Using these data, the temperature-humidity index (THI) was calculated, following NRC (1971) recommendations:

$$
\begin{aligned}
\mathrm{THI}=(1.8 \times \mathrm{T}+32)-[(0.55-0.0055 \times \mathrm{RH}) \\
\\
\times(1.8 \times \mathrm{T}-28.8)] .
\end{aligned}
$$

\section{Statistical Analysis}

First, the distribution of variables was analyzed using box-plots, histograms, and normal probability plots. The SCC values $(\times 1,000$ cells $/ \mathrm{mL})$ were transformed into base-10 logarithm to normalize their distributions.

The association between the explanatory variables and cortisol was assessed using a stepwise linear mixed model procedure. Factors and first-order interaction terms that were significant at $P<0.05$ were included in the final model (Proc Mixed, version 9.1., 2002, SAS Institute Inc., Cary, NC). This included cortisol as outcome variable and the following explanatory variables: HS (4 levels: IMI1, IMI2, FREE1, and FREE2), lactation stage (LS; 8 levels: $1,2, \ldots, 8$ mo of lactation), parity number (PN; 4 levels: $1=$ first parity, $2=$ second parity, $3=$ third parity, $4=4$ parities or more), and the interaction of LS with PN. Goat was considered a random term. In addition, we used a compound symmetry covariance structure to account for the repeated measurements over time on the same animals. The model using this hierarchical structure provided the best fit for the variable when compared with different models considering other covariance and hierarchical structures (as assessed using Bayesian and Akaike information criteria).
The relationships between cortisol and the other variables of milk composition, yield, and machine milking ability of goats were studied using Pearson correlation coefficients (PROC CORR, SAS Institute Inc.).

\section{RESULTS}

\section{Evolution of Variables During the Experiment}

Table 1 shows the average value of $\mathrm{T}$ and $\mathrm{RH}$ recorded and THI calculated on the farm in the $24 \mathrm{~h}$ before the sampling day $(24 \mathrm{~h})$ and the difference (Diff) between the average value $24 \mathrm{~h}$ before starting sampling and the average values $7 \mathrm{~d}$ before the sampling day for each of these variables. Both $\mathrm{T}$ and THI increased from the start (February) until mo 7 (August) and decreased again in mo 8 (September). The highest specific difference in THI was observed on sampling d 5 (3.1 points) as a consequence of an average increase of $\mathrm{T}\left(2.4^{\circ} \mathrm{C}\right)$ and a decrease in $\mathrm{RH}(-2 \%)$. In each of the 24-h periods before sampling on d 5 , a difference in THI of more than 2 points was observed, eventually reaching 5 points of difference. Likewise, the lowest specific difference in THI occurred in mo $2(-3.6$ points) because of an average decrease in $\mathrm{T}\left(-1.8^{\circ} \mathrm{C}\right)$ and an increase in RH (16.4\%). In this case, we also observed a negative difference in THI in the $24 \mathrm{~h}$ before sampling, with nighttime readings reaching -8.2 points of difference.

All groups of animals tended to experience similar decreases in MY (Figure 1a) and MM (Figure 1b) during lactation, according to parity number. On all sampling days, a higher yield from third-parity animals and a lower yield from first-parity animals were noted. However, MSM (Figure 1c) did not show a similar evolution during lactation for all groups of animals, because the volume of milk for this fraction was lower and more constant during lactation in first-parity goats than in the other animals. The evolution of MY, MM, and MSM was affected in mo 5 for first-parity, third-parity, and animals of $\geq 4$ parities: MY and MM showed a specific decrease and MSM a specific increase. In mo 2, a slight decrease in MY and MM and a slight increase in MSM were observed in third-parity animals.

Contents of fat, total protein, and lactose presented similar evolution during lactation for all groups of animals, according to PN. We observed that, on almost all sampling days, the higher the production levels, the lower the concentration of components in milk; the lowest concentration of these components was found in third-parity animals. Another aspect to highlight is that fat content increased slightly, as did total protein on sampling d 2 and 5, mainly for third-parity animals. On the other hand, lactose content decreased during 
Table 1. Average temperature value (T), relative humidity $(\mathrm{RH})$, and temperature-humidity index (THI) $24 \mathrm{~h}$ before starting sampling (24 h) and the difference (Diff) between the average value $24 \mathrm{~h}$ before starting sampling and the average value of the $7 \mathrm{~d}$ before the sampling day for each of these variables

\begin{tabular}{|c|c|c|c|c|c|c|c|c|c|c|c|c|c|c|c|c|}
\hline \multirow[b]{2}{*}{ Variable $^{1}$} & \multicolumn{2}{|c|}{ Month 1} & \multicolumn{2}{|c|}{ Month 2} & \multicolumn{2}{|c|}{ Month 3} & \multicolumn{2}{|c|}{ Month 4} & \multicolumn{2}{|c|}{ Month 5} & \multicolumn{2}{|c|}{ Month 6} & \multicolumn{2}{|c|}{ Month 7} & \multicolumn{2}{|c|}{ Month 8} \\
\hline & $24 \mathrm{~h}$ & Diff & $24 \mathrm{~h}$ & Diff & $24 \mathrm{~h}$ & Diff & $24 \mathrm{~h}$ & Diff & $24 \mathrm{~h}$ & Diff & $24 \mathrm{~h}$ & Diff & $24 \mathrm{~h}$ & Diff & $24 \mathrm{~h}$ & Diff \\
\hline $\mathrm{T}\left({ }^{\circ} \mathrm{C}\right)$ & 10.6 & -0.2 & 12.2 & -1.8 & 16.6 & 0.4 & 20.2 & 1.2 & 21.7 & 2.4 & 26.9 & 0.3 & 27.2 & -0.2 & 25.5 & -1.9 \\
\hline RH (\%) & 80.1 & 5.7 & 76.8 & 16.4 & 62.9 & 13.6 & 61 & 6.5 & 65.1 & -2 & 56.9 & -1.4 & 69 & 9 & 72.6 & 3.9 \\
\hline THI & 51.7 & -0.4 & 54.3 & -3.6 & 61.3 & 0.9 & 66.1 & 1.7 & 68.4 & 3.1 & 75.1 & 0.1 & 76.8 & 0.7 & 74.8 & -2.4 \\
\hline
\end{tabular}

${ }^{1} \mathrm{THI}=(1.8 \times \mathrm{T}+32)-[(0.55-0.0055 \times \mathrm{RH}) \times(1.8 \times \mathrm{T}-28.8)]$.
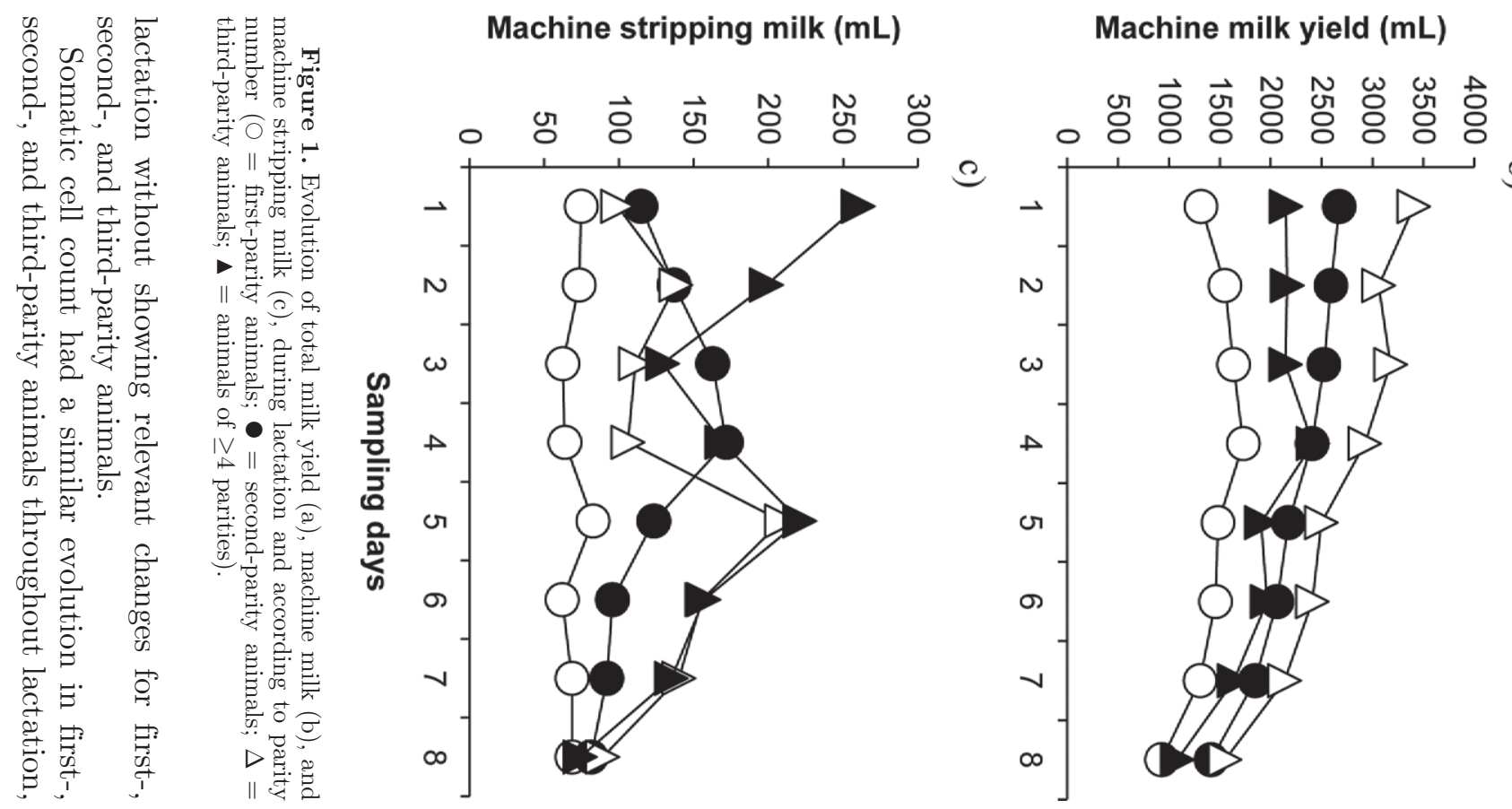

Total milk yield $(\mathrm{mL})$

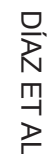

(1) 
with values $<400,000$ cells $/ \mathrm{mL}$ (geometric average) on the 8 sampling days. In the case of animals with 4 or more parturitions, SCC presented a tendency to increase throughout lactation, exceeding 1,000,000 cells/ $\mathrm{mL}$ as of the fifth sampling. A specific increase in SCC was noted in mo 2 for third-parity animals and in mo 5 for animals of parity 3,4 or more.

\section{Effect of Fixed Factors on Milk Cortisol Concentration}

Lactation stage $(P<0.001)$, PN $(P<0.01)$, and the interaction between LS and PN $(P<0.001)$ had a significant effect on milk cortisol concentration. On the other hand, HS did not have a significant effect on cortisol. Average milk cortisol concentration during the experiment was $0.46 \pm 0.43 \mathrm{ng} / \mathrm{mL}$, with a minimum value of $0.02 \mathrm{ng} / \mathrm{mL}$ and maximum value of $5.45 \mathrm{ng} / \mathrm{mL}$. Milk cortisol concentration was highest in the first $2 \mathrm{mo}$ of the experiment $(0.53 \pm 0.06$ and 0.51 $\pm 0.06 \mathrm{ng} / \mathrm{mL}$ for mo 1 and 2 , respectively), although it tended to decrease during lactation until reaching a value of $0.31 \pm 0.06 \mathrm{ng} / \mathrm{mL}$ in mo 8 (Figure 2a). A significant increase was noted in mo $5(0.89 \pm 0.05$ $\mathrm{ng} / \mathrm{mL})$, and the lowest value was in mo $6(0.52 \pm$ $0.06 \mathrm{ng} / \mathrm{mL}$ ). Cortisol increased in mo 5 in all groups of animals, but more markedly in third-parity goats (Figure 3), in which an increase in cortisol was also observed at mo 6. Animals in third parity showed a significantly higher average milk cortisol concentration during the experiment than did animals of first, second, and fourth parity or more (Figure $2 \mathrm{~b}$ ).

Health status was not related to milk cortisol concentration (Figure 2c). The number of cases for each of the HS levels was as follows: IMI $1=80$, IMI $2=129$, FREE1 $=228$, and FREE2 $=16$. Similarly, we found no significant correlation between cortisol and SCC. In fact, animals of $\geq 4$ parities that had a high SCC during lactation did not show a higher level of cortisol in milk than the rest of the animals (Figure 3).

We found positive correlations of cortisol concentration with MY $(\mathrm{r}=014 ; P<0.01)$ and MM $(\mathrm{r}=0.14$; $P<0.01$ ). However, no significant correlations were found with MSM and MT or with the other milk components (fat, total protein, and lactose).

\section{DISCUSSION}

The average milk cortisol concentration observed in this experiment $(0.46 \mathrm{ng} / \mathrm{mL})$ lies within the range of values observed in cows (Verkerk et al., 1998: 0.5 to $11.7 \mathrm{ng} / \mathrm{mL}$, according to experimental group; Fukasawa and Tsukada, 2010: 0.355 ng/mL). With respect to the evolution of cortisol concentration during lac- tation, the results obtained in this experiment are in agreement with Fukasawa et al. (2008), who found that milk cortisol concentrations in cows were higher at the onset of lactation. Different researchers indicate that mechanical milking of cows can be stressful during their first milkings, especially in primiparous cows, due to the interaction with humans and contact with the new facilities (Van Reenen et al., 2002; Negrão, 2008).

The significant and specific increase in milk cortisol concentration recorded in mo 5 of lactation occurred in almost all experimental animals and was greater in third-parity animals. In the moments leading up to sampling on $\mathrm{d} 5$ and on the previous days, no special management of animals was carried out (e.g., vaccinations, rehousing, identification, manure removal), so as to avoid causing any stress. However, on this day, the highest increase in THI (3.1 points) was observed because of an increase in $\mathrm{T}\left(+2.4^{\circ} \mathrm{C}\right)$ and a decrease in $\mathrm{RH}(-2 \%)$, causing a dry atmosphere that could have affected the thermal comfort of the animals. A comparison between the hourly records for the $24 \mathrm{~h}$ before starting sampling and the average for the previous week (data not shown) showed that from $1500 \mathrm{~h}$ the previous afternoon, the average $\mathrm{T}$ increased by more than $5^{\circ} \mathrm{C}$ and $\mathrm{RH}$ decreased more than $25 \%$, causing an increase in THI at all time points, up to 5 units in some hourly periods. Unlike that observed in the nights before other sampling days, the difference in THI was positive at all times by a minimum of 2 points on the night before milking on d 5 .

Different authors point out that THI is the indicator most used for relating thermal and climatic conditions with stress in cows (West, 2003). If the specific value of THI (without an adaptation period for the animals) is $>72$, cows can suffer heat stress (West, 2003). When the value is between 78 and 82 , cows can be seriously affected and cooling is fundamental, and if it is $>82$, the cow can die of thermal stress (Du Preez et al., 1990).

No studies have yet established the THI thresholds that affect goats. On the fifth day of sampling in this experiment, THI reached 68 points and, although in some of the subsequent months THI exceeded 75 points, it was in the fifth month when the greatest continuous positive THI differences were found in the hours before sampling began. The ongoing and sharp increase in THI may have led to thermal stress in the animals and a change in their feeding behavior and habits, which predisposed them to be more sensitive to any stress factor that arose before milking and was not detected by the researchers. The increase might also have caused greater stimulation of the adrenal glands, causing a basal elevation of cortisol in plasma and in milk, or both situations may have occurred. Thinh et 
a)

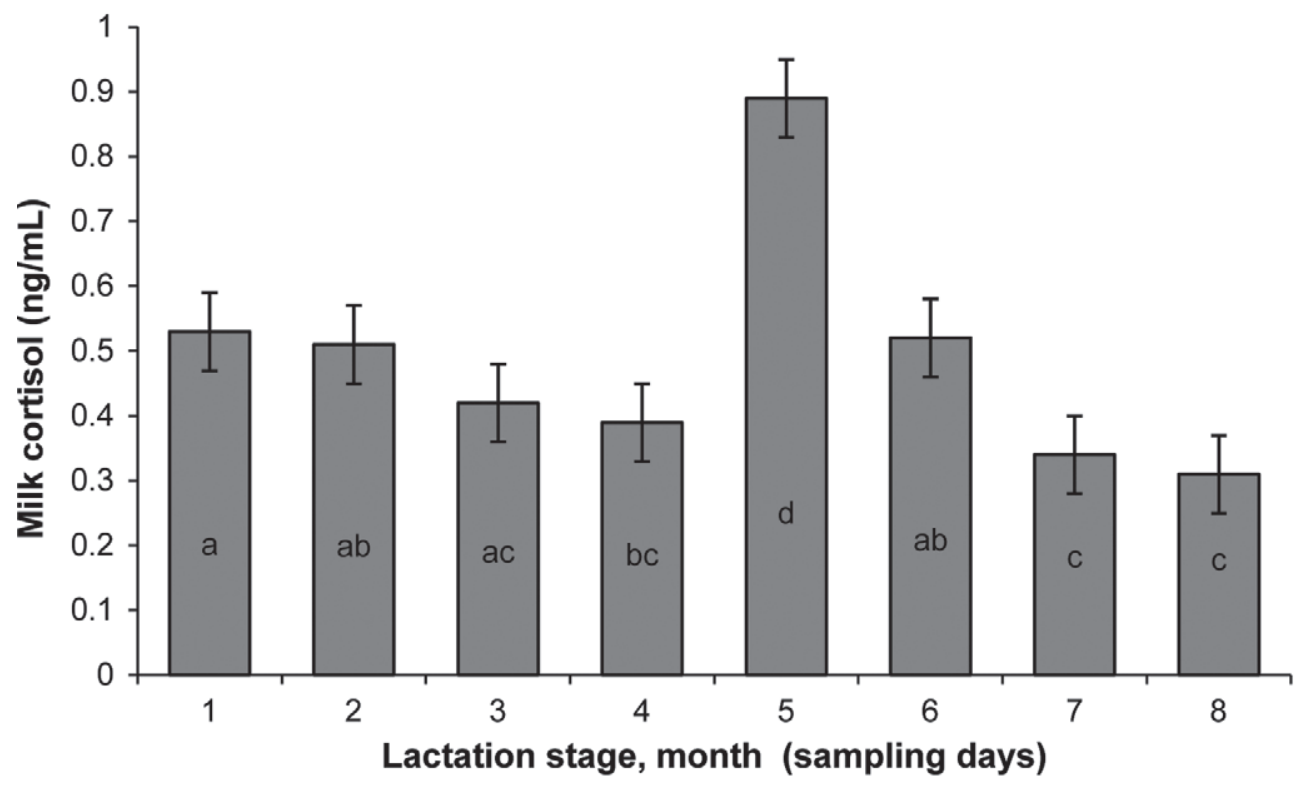

b)

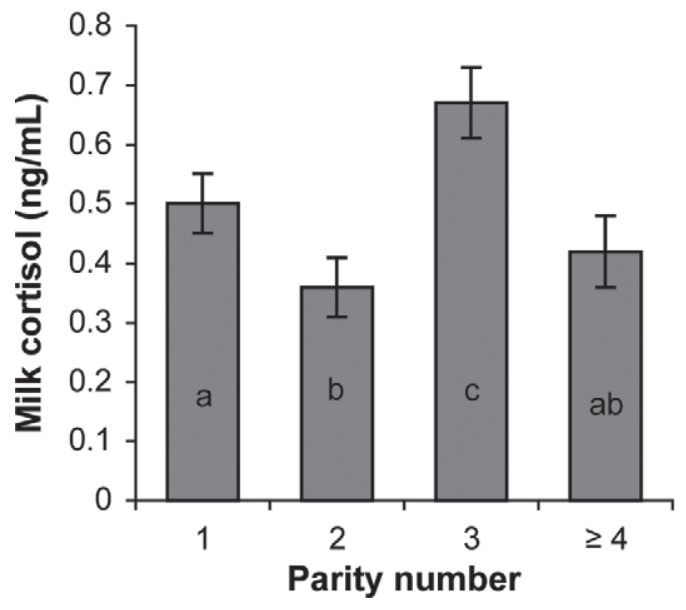

c)

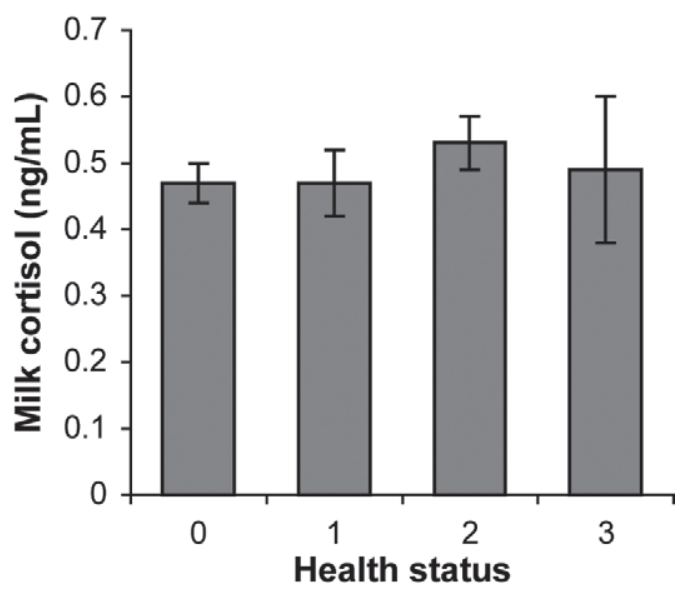

Figure 2. Effect of lactation stage (a), parity number (b), and health status (c) on milk cortisol concentration Health status: $0=$ negative bacteriology and low SCC (FREE1); 1 = positive bacteriology and high SCC (IMI1); $2=$ positive bacteriology and low SCC (IMI2); $3=$ negative bacteriology and high SCC (FREE2), where low SCC is $<1,000 \times 10^{3}$ cells $/ \mathrm{mL}$ and high SCC is $>1,000 \times 10^{3}$ cells $/ \mathrm{mL} .{ }^{\mathrm{a}-\mathrm{d}} \mathrm{Means}$ within a factor with different letters differ $(P<0.05)$.

al. (2011) described, in dairy cows, how the plasma cortisol concentration was increased for up to $10 \mathrm{~h}$ after stimulation of the adrenals with long-acting ACTH and that the maximum cortisol concentration was seen for $8 \mathrm{~h}$ after injection. West (2003) noted that extreme heat stress causes an increase in plasma cortisol level in cows, which could be related more to an emotional response than to a thermoregulation response (Collins and Weiner, 1968). Olsson and Dahlborn (1989) indicated that heat stress does not produce an increase in plasma cortisol levels in goats. However, those authors reported that the combination of heat stress and de- hydration due to low RH (increase in THI) caused an increase in plasma cortisol of lactating goats.

Lee et al. (1976) described how prolonged exposure to high temperatures causes a decrease in base levels of cortisol, which could be due to specific endocrine changes aimed at eliminating endogenous heat production (Gudev et al., 2005). This could explain why, in the months following sampling on $\mathrm{d} 5$, we observed a progressive decrease in cortisol along with a progressive increase in THI, indicating that the animals could have gone through a period of adaptation to higher THI values (Lee et al., 1976). 


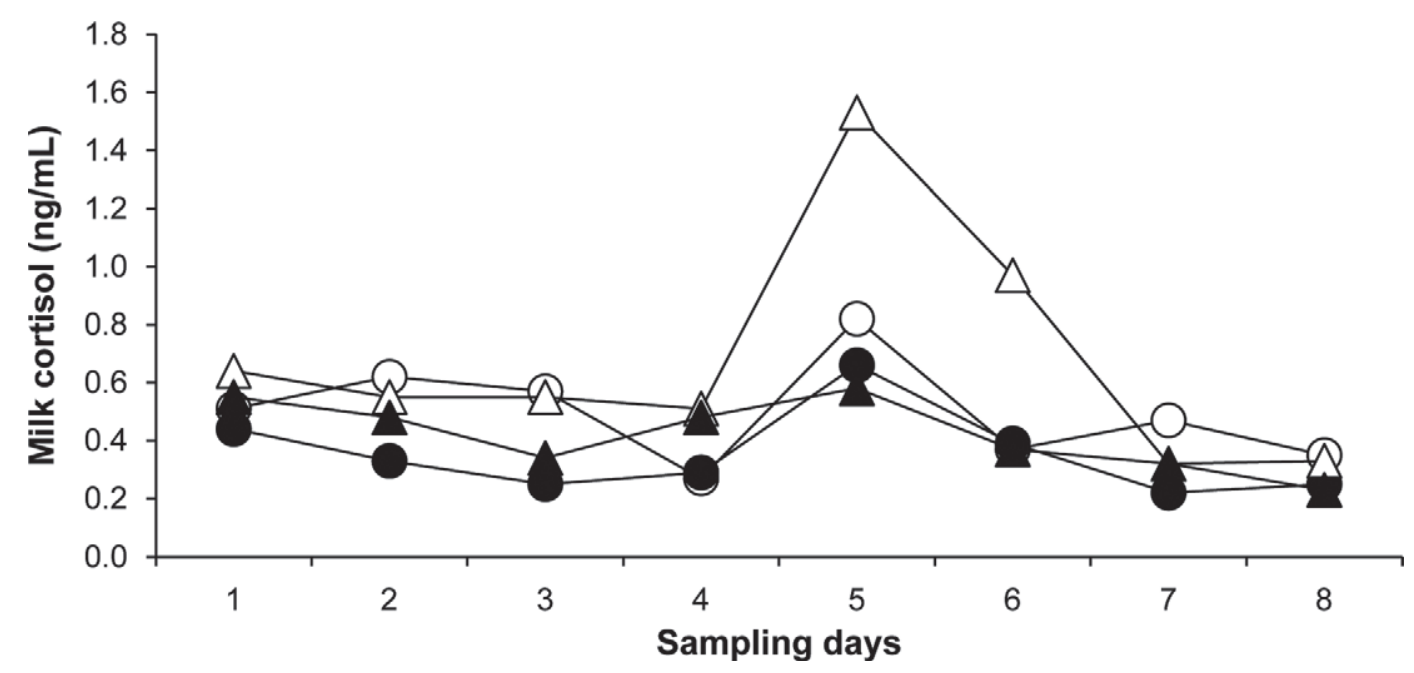

Figure 3. Evolution of average value of milk cortisol concentration $(\mathrm{ng} / \mathrm{mL})$ during lactation by parity number $(O=$ first-parity animals; $=$ second-parity animals; $\Delta=$ third-parity animals; $\boldsymbol{\Lambda}=$ animals of $\geq 4$ parities).

In mo 5 of lactation, a decrease in MY and an increase in fat and total protein percentages were also observed (principally for third-parity animals). In this study, the increase in $\mathrm{T}$ and decrease in $\mathrm{RH}$ (and thus increase in THI) occurring sharply and specifically on the day before sampling in mo 5 could have caused thermal stress, which would lead to an increase in milk cortisol levels and a change in eating behaviors (a decrease in food consumption and higher water intake), which could be related to a decrease in MY and consequently an increase in fat and total protein concentrations. This physiological alteration might predispose the animals to be more sensitive to a stress factor, thereby increasing the cortisol concentration in the milk. Dahlborn (1987) indicates that during the restriction of food consumption, milk production is reduced and protein and fat content in goat milk increases. The same could have happened, albeit to a lesser extent, on the second sampling day, where a sharp decrease in THI $(-3.6$ points) affected eating behavior, causing a slight decrease in MY and a small increase in fat and total protein, observed mainly in third-parity animals. In this case, cortisol concentration did not increase, which may be because the variation in climatic conditions that occurred on the day before sampling (negative differences in THI and maximum THI values of 55 points), despite affecting the animals' thermal comfort, may not have caused the same thermal stress as occurred in the day before the first day of sampling.

The positive association of milk cortisol with fat and total protein observed during mo 5 does not correspond to that found when all data from the experiment were considered, given that a significant correlation of cortisol with these 2 variables was not observed. Fukasawa et al. (2008) did not find a significant relation between cortisol and fat content, although those authors did find a negative correlation between cortisol and total protein content $(\mathrm{r}=-0.33)$.

Milk cortisol concentration was correlated with MY and MM but not with MSM and MT, perhaps because overmilking did not occur, as milking times were similar to those found by other authors for the same breed (Vidal et al., 2008). Excessive milking time can produce teat tissue changes and stress the animal, especially when it is overmilked. Fukasawa et al. (2008) did not find a correlation between milk cortisol and milk production in cows.

Parity number had a significant effect on milk cortisol levels, and a higher average cortisol concentration was found in milk from third-parity animals. Milk cortisol concentration during lactation was higher in first- and third-parity animals. In cows, Fukasawa et al. (2008) did not find significant differences in milk cortisol concentration from animals with different parities, and Mehdid (2009) points out that, in goats under the same stressful stimulation, animals of parity 3 or more can suffer greater stress than first- or second-parity goats and a higher level of plasma cortisol is noted.

All the animals were in mixed housing, so third-parity animals received the same management, the same food, and the same housing conditions as the rest of the animals. These animals showed higher MY and MM and presented SCC values $<400,000$ cells $/ \mathrm{mL}$, similar to those of first- and second-parity goats. These results suggest that the highest concentration of cortisol observed in these animals on all sampling days was caused by a physiological condition of these animals and was not related to stress in the period before milking (one 
exception may be what happened on d 5), as MY would have been affected as well as the immune system (von Borrel, 2001). Negrão and Marnet (2006), in an experiment on Holstein and Holstein $\times$ Gyr cows, found that animals with higher milk yield showed higher levels of plasma cortisol. Similar results were found by Macuhová et al. (2002), where cows that were more sensitive to stress or to the ACTH injection produced a greater quantity of milk during normal milking. Bernabucci et al. (2010) note that dairy cows with high milk yield are more susceptible to heat stress than those with low milk yield, because they generate more metabolic heat. This could explain the higher concentration of cortisol observed in goats in third parity during lactation and the greater increase of milk cortisol observed in mo 5 and 6 of the experiment.

Intramammary infection did not affect the cortisol concentration in milk, possibly because the subclinical mastitis suffered by the infected animals did not affect their welfare sufficiently to raise the milk cortisol levels. The IMI could have been caused by different microorganisms with different immune responses in the mammary glands (higher SCC: IMI1; lower SCC: IMI2), which did not correspond to a higher or lower cortisol concentration, respectively, in the milk. Nor was any such correspondence observed in those animals without IMI (higher SCC: FREE2; lower RCS: FREE1). Thus, no significant correlation was found between the milk cortisol concentration and SCC. Fukasawa et al. (2008) did not find a significant correlation between SCC and milk cortisol concentration in cows, and Decarvalho et al. (2009) did not find a relationship between SCC and cortisol level in saliva in Norwegian goats, and even found that high levels of SCC were related to the lowest levels of cortisol. Fox et al. (1981) observed a higher cortisol concentration in milk from swollen glands than in milk from healthy glands (1.75 vs. $0.84 \mathrm{ng} / \mathrm{mL}$, respectively). However, in that experiment, mastitis was induced through the application of endotoxin from Escherichia coli, which produced a substantial increase in SCC (from a low of $100 \times 10^{3}$ to a high of 2,000 $\times 10^{3}$ cells $/ \mathrm{mL}$ ) and severe udder swelling. Hockett et al. (2000) also found a significant increase in the level of cortisol in blood at 4 and $7 \mathrm{~d}$ after inducing IMI with Streptococcus compared with preinfection values. In contrast, Mehdid (2009) states that if severe stress occurs, the level of cortisol in blood increases and SCC increases, although this increase in SCC is only found in goats of 3 or more parities. It is possible that because of the sampling interval in this study, we failed to identify effects of the IMI on cortisol or that the infections recorded were not serious enough to produce a significant increase in milk cortisol.

\section{CONCLUSIONS}

Determining the concentration of cortisol in milk might be a suitable method to assess the extent to which extrinsic factors (e.g., management, mechanical milking, food, type of housing, environmental conditions) cause stress in Murciano-Granadina goats, affecting their welfare. However, the use of milk cortisol concentration as a result of a specific and isolated analysis on a farm should be analyzed in depth, given that physiological factors other than stress (milk production, parity number, and lactation stage) affect milk cortisol concentration.

\section{ACKNOWLEDGMENTS}

The study was supported by project AGL200606909 (Ministerio de Educación y Ciencia of Spain and FEDER).

\section{REFERENCES}

Bernabucci, U., N. Lacetera, L. H. Baumgard, R. P. Rhoads, B. Ronchi, and A. Nardone. 2010. Metabolic and hormonal acclimation to heat stress in domesticated ruminants. Animal 4:1167-1183.

Bonafos, L., D. Simonin, and A. Gavinelli. 2010. Animal welfare: European legislation and future perspectives. J. Vet. Med. Educ. $37: 26-29$.

Canaes, T. S., J. A. Negrão, F. A. Paiva, M. Zaros, and T. F. Delgado. 2009. Physiologic and productive responses of Alpine goats submitted to transportation to a new dairy location. Arq. Bras. Med. Vet. Zootec. 61:935-940.

Chacón, G., S. García-Belenguer, J. C. Illera, and J. Palacio. 2004. Validation of an EIA technique for the determination of salivary cortisol in cattle. Span. J. Agric. Res. 2:45-51.

Collins, K. J., and H. S. Weiner. 1968. Endocrinological aspects of exposure to high environmental temperatures. Physiol. Rev. 48:785-839.

Comin, A., A. Prandi, T. Peric, M. Corazzin, S. Dovier, and S. Bovolenta. 2011. Hair cortisol levels in dairy cows from winter housing to summer highland grazing. Livest. Sci. 138:69-73.

Dahlborn, K. 1987. Effect of temporary food or water deprivation on milk secretion and composition in the goat. J. Dairy Res. 54:153-163.

Decarvalho, M., E. Simensen, N. Fjerdingby, S. Larsen, and A. Zanella. 2009. Measuring welfare indicators in dairy goats through salivary cortisol and somatic cell counts (SCC). Pages 499-502 in Husdyrfors $\varnothing$ ksm $\varnothing$ tet Lillestrøm Norge. Norwegian University of Life Sciences (UMB), Ås, Norway.

Du Preez, J. H., W. H. Giesecke, and P. N. Hattingh. 1990. Heat stress in dairy cattle and other livestock under southern African conditions. I. Temperature-humidity index mean values during the four main seasons. Onderstepoort J. Vet. Res. 57:77-87.

Fox, L. K., C. W. Heald, F. C. Gwazdauskas, and W. E. Vinson. 1981. Concentrations of glucocorticoids, bovine serum albumin, and somatic cells in mastitic milk. J. Dairy Sci. 64:2258-2261.

Fukasawa, M., and H. Tsukada. 2010. Relationship between milk cortisol concentration and the behavioral characteristics of postpartum cows introduced to a new group. Anim. Sci. J. 81:612-617.

Fukasawa, M., H. Tsukada, T. Kosako, and A. Yamada. 2008. Effect of lactation stage, season and parity on milk cortisol concentration in Holstein cows. Livest. Sci. 113:280-284.

Gudev, D., S. Popova-Raltcheva, P. Moneva, and H. D. Johnson. 2005. Endocrine changes in two behavioural types of cows exposed to heat. Biotech. Anim. Husb. 21:45-51. 
Gygax, L., I. Neuffer, C. Kaufmann, R. Hauser, and B. Wechsler. 2006. Milk cortisol concentration in automatic milking systems compared with auto-tandem milking parlors. J. Dairy Sci. 89:3447-3454.

Hagen, K., D. Lexer, R. Palme, J. Troxler, and S. Waiblinger. 2004. Milking of Brown Swiss and Austrian Simmental cows in a herringbone parlour or an automatic milking unit. Appl. Anim. Behav. Sci. 88:209-225.

Hockett, M. E., F. M. Hopkins, M. J. Lewis, A. M. Saxton, H. H. Dowlen, S. P. Oliver, and F. N. Schrick. 2000. Endocrine profiles of dairy cows following experimentally induced clinical mastitis during early lactation. Anim. Reprod. Sci. 58:241-251.

ISO/FIL (International Organization for Standardization). 2006. Milk. Enumeration of somatic cells. Part 2: Guidance on the operation of fluoro-opto-electronic counters. ISO 13366-2/IDF 148-2. ISO, Geneva, Switzerland.

Lee, J. A., J. D. Roussel, and J. F. Beatty. 1976. Effect of temperatureseason on bovine adrenal cortical function, blood cell profile, and milk production. J. Dairy Sci. 59:104-108.

Macuhová, J., V. Tancin, W. D. Kraetzl, H. Meyer, and R. M. Bruckmaier. 2002. Inhibition of oxytocin release during repeated milking in unfamiliar surroundings: The importance of opioids and adrenal cortex sensitivity. J. Dairy Res. 69:63-73.

Marsico, G., E. Micera, S. Dimatteo, F. Minuti, A. Vicenti, and A. Zarrilli. 2009. Evaluation of animal welfare and milk production of goat fed on diet containing hydroponically germinating seeds. Ital. J. Anim. Sci. 8:625-627.

Mehdid, M. A. 2009. Efecto del celo y del estrés sobre el recuento de células somáticas en la leche de cabra [Effect of estrus and stress on somatic cell count in goat milk]. Doctoral Thesis. Universidad Politecnica, Valencia, Spain. http://riunet.upv.es/bitstream/ handle/10251/6846/tesisUPV3201.pdf.

Möstl, E., and R. Palme. 2002. Hormones as indicators of stress. Domest. Anim. Endocrinol. 23:67-74.

Munro, C. J., and B. L. Lasley. 1988. Non-radiometric methods for immunoassay of steroid hormones. Prog. Clin. Biol. Res. 285:289 329.

NRC. 1971. A Guide to Environmental Research on Animals. National Academy of Science, Washington, DC.

Negrão, J. A. 2008. Hormone release and behavior during suckling and milking in Gir, Gir $\times$ Holstein, and Holstein cows. J. Anim. Sci. 86:21-26.

Negrão, J. A., and P. G. Marnet. 2006. Milk yield, residual milk, oxytocin and cortisol release during machine milking in Gir, Gir $\times$ Holstein and Holstein cows. Reprod. Nutr. Dev. 46:77-85.
Negrão, J. A., M. A. Porcionato, A. Passille, and J. Rushen. 2004. Cortisol in saliva and plasma of cattle after ACTH administration and milking. J. Dairy Sci. 87:1713-1718.

Olmos, G., J. F. Mee, A. Hanlon, J. Patton, J. J. Murphy, and L. Boyle. 2009. Peripartum health and welfare of Holstein-Friesian cows in a confinement-TMR system compared to a pasture-based system. Anim. Welf. 18:467-476.

Olsson, K., and K. Dahlborn. 1989. Fluid balance during heat stress in lactating goats. Q. J. Exp. Physiol. 74:645-659.

Palme, R., P. Fischer, H. Schildorfer, and M. N. Ismail. 1996. Excretion of infused C-steroid hormones via faeces and urine in domestic livestock. Anim. Reprod. Sci. 43:43-63.

Sevi, A. 2009. Animal-based measures for welfare assessment. Ital. J. Anim. Sci. 8(Suppl. 2):904-911.

Sevi, A., G. Annicchiarico, M. Albezio, L. Taibi, A. Muscio, and S. Dell'Aquila. 2001. Effects of solar radiation and feeding time on behavior, immune response, and production of lactating ewes under high ambient temperature. J. Dairy Sci. 84:629-640.

Thinh, N. C., C. Yoshida, S. T. Long, M. Yusuf, and T. Nakao. 2011. Adrenocortical response in cows after intramuscular injection of long-acting adrenocorticotropic hormone (tetracosactide acetate zinc suspension). Reprod. Domest. Anim. 46:296-300.

Trevisi, E., R. Lombardelli, A. Minuti, and G. Bertoni. 2009. Adrenal responsiveness to a low-dose $\mathrm{ACTH}$ challenge in early and late lactating dairy cows. Ital. J. Anim. Sci. 8:661-663.

Van Reenen, C. G., J. T. van der Werf, R. M. Bruckmaier, H. Hopster, B. Engel, and J. P. Noordhuizen. 2002. Individual differences in behavioral and physiological responsiveness of primiparous dairy cows to machine milking. J. Dairy Sci. 85:2551-2561.

Verkerk, G. A., A. M. Phipps, J. F. Carragher, L. R. Matthews, and K. Stelwagen. 1998. Characterisation of milk cortisol concentrations as a measure of short-term stress responses in lactating dairy cows. Anim. Welf. 7:77-86.

Vidal, G., E. Gomez, B. Martinez, M.A. Mehdid, and C. Peris. 2008. La velocidad de ordeño en cabras Murciano-Granadinas. Pages 149-157 in Libro de actas de XXXIII Jornadas Científicas y XII Internacionales de la SEOC. Almería Junta de Andalucía, Almería, Spain.

von Borrel, E. H. 2001. The biology of stress and its application to livestock housing and transportation assessment. J. Anim. Sci. $79: 260-267$.

West, J. W. 2003. Effects of heat-stress on production in dairy cattle. J. Dairy Sci. 86:2131-2144. 